\title{
PASTORAL FARMING PRACTICE AND PHILOSOPHY 1974
}

\author{
J. A. H. INGLis \\ Farmer, "Ratahiwi", Woodville
}

Abstract

The operator of an economic unit of North Island pastoral land describes some of his current practices in order to define areas in which progress is being made, as well as areas where he meets distinct problems. Some thought is given to directions where management and more importantly thinking may be able to move in future.

THE WRITER read a paper at the New Zealand Grassland Conference nine years ago (Inglis, 1965), The main justification for publishing another on a similar theme is that the thinking of those days is now well out of date. As one cannot destroy the published literature, the next best thing is to produce another paper, for otherwise harm will be done by persons having a fossilized knowledge of a farming programme.

The farm known as "Ratahiwi" is really two properties, one owned by my sister, Mrs Helen Soundy, and one owned by the writer. The total present area of 614 ha is farmed as a partnership without capital. The farm has been owned by the present owners' family since 1914, but has been increased in size from 341 ha by purchases in 1951, 1964, 1965 and 1969. Land varies from almost flat through to steep, height from 160 to $400 \mathrm{~m}$. Soil types are:

$40 \%$ gleyed intergrades between yellow-brown earths and yellow-grey earths, and some associated steepland soils.

$40 \%$ yellow-brown earths and associated steepland soils.

$10 \%$ recent soils, mostly sandy and gleyed.

$10 \%$ intergrades between yellow-brown earths and yellowbrown loams.

Soils are formed from loess derived from greywacke containing some volcanic ash, greywacke-derived alluvium, and sedimentary sandstones and siltstones (Rijkse, 197 1) .

As may be expected in a rainfall varying from $1300 \mathrm{~mm}$ on lower country to an estimated $2000 \mathrm{~mm}$ at the top, these soils were originally short of phosphate and molybdenum, but were 
otherwise satisfactory for pasture and stock health, except that $\mathrm{pH}$ values ranging from 5.2 to 5.6 were less than optimum.

The earlier stages of development on "Ratahiwi" consisted of:

(a) Using what grass grew.

(b) Oversowing clovers by hand.

(c) Topdressing with superphosphate, at rates thought heavy in the early 1950s, plus occasional dressings with molybdenum after it was recommended by Blackmore as local Farm Advisory Officer.

(d) Fencing to give reasonable stock control.

(e) Some roading.

These sorts of things were of interest at the time but in development of New Zealand hill country have really passed into history. The only points in our thinking and management which have current interest date from 1969 onwards.

This paper is not a success story of vast increases in productivity but rather describes consolidation, and a study of management practices; expansion of the total undertaking occurred by land purchase. We hope we have done some useful exercises in constructive thinking, and applied them. Difficulties in the shape of previously unknown autumn droughts have been experienced in five consecutive years; how much results have been due to climatic variation and how much to a change to ryegress dominance with its low heat resistance are difficult to define.

It appears that pasture composition and vigour are now improving after some time when they did not.

Details of financial results are not offered as part of this paper, though our standard of living has been rising. A new farm dwelling was built in 1971 .

$$
\text { STOCK POLICY }
$$

\section{SHEEP}

For many years a Romney flock was run, and steers were bought and sold for grazing control. Set-stocking was practised and was probably suitable under conditions where self-rationing (because of low palatability) grasses were dominant, and paddocks were limited in numbers.

By 1969 , with a very considerable improvement in pasture species, coupled with the first of a series of dry summers which 
made stock lose condition in autumn, it became evident that some better management was required. In 1970 we had arrived at a position of having 90 paddocks each of about 8 to 10 ha on the hills and 5 ha in the more productive valleys. What was more important, our own thinking had advanced to a stage where we could design some sort of a workable rotation, using the approach to grazing management which was being expounded by Brougham. We divided the flock of 6500 ewes into two groups with daily shifts over a 28-day rotation; they put on condition through what was generally regarded as a difficult winter which followed a dry autumn.

Historically it is interesting to remember that this sort of management was regarded by most other farmers as revolutionary 'in 1970; by 1974 only the finer points to which we have moved are of interest to many farmers.

Grazing management of the ewes through lambing and lactation has remained something close to set-stocking. After a visit to Grasslands regional station at Gore in 1972, the writer came to the conclusion that management through lactation would be better on a rotation if we had, say, 250 paddocks each of 2.4 ha, to enable us to work smaller groups than in winter. We have not, for probably obvious reasons of cost, engineering difficulties, and sheer problems of co-ordinetioa on our area, faced up to this as yet; this is a field for future study and decision.

Results of 1970 grazing in sheep thrift and pasture improvement were so encouraging that from 1971 onwards we have rotated our ewes from February to August, and our ewe hoggets from May to August. We do not think rotation of ewes very practicable during lambing with our climate, soils and contours. The reason for stopping the hogget rotation in August has been that the labour force of three has been fully occupied on lambing beats.

We have now (March, 1974) largely completed a change to Perendale sheep, which seem most suited to the steeper yellowbrown earths on the higher part of the property, while the lower country is projected to move further into cattle. One could very well run, say, Coopworth or Romney on the lower hills, but I have no wish to maintain two flocks.

By winter of 1973 our management, or more particularly our thinking, had progressed to the stage where we achieved a rotation of 52 days for the ewes in two groups, and 28 days for the 2500 ewe hoggets. This meant sheep were often in a paddock 
for two consecutive days. It has been demonstrated that sheep will thrive on a meal every second day, provided total food intake is sufficient. Pugging is the problem on the second day and if we strike wet weather it is probably better to move on after 24 hours. My observation is that on daily shifts the sheep graze all morning, chew their cud in the afternoon, and sleep till a little after sunrise in winter. When they wake up they look for food and most trampling damage occurs if the gate is not open at that time. We are wondering whether to use electric fences more extensively - they seem to have limitations on steeper and broken land, but would give cheap subdivision.

The ewe flock has been maintained between 6000 and 7000 , with about 2500 ewe hoggets. In future we expect no more sheep and an increase in cattle. Ewes have not bean sorted for lambing dates, but any ewes proved empty after two cycles are marked by harnessed rams and sent for slaughter. These constitute 1 to $1.5 \%$ of the flock.

\section{CATTLE}

A change in cattle policy is now being tried. Thirty heifers were acquired and mated to calve in 1973. Ten others purchased as empty had calved in January and February 1973, which from observation might be quite a profitable date. Seventy-five weaner Angus heifers suitable for breeding were purchased in April 1973, with the dual objectives of having more breeders available, and of finding out how successful we would be at intensive rearing on grass alone. We were and are thinking of running several hundred calves in several groups in 1974. The weaners, on a 47-day rotation using $18 \mathrm{ha}$, did very well on grass alone. In April, $60 \mathrm{~kg} / \mathrm{ha}$ of $\mathrm{N}$ as urea was applied, and response continued at least intc October.

A management decision must soon be taken whether to:

(a) Run only weaners, and sell the breeders.

(b) Keep a small herd and buy some weaners.

(c) Substantially increase numbers of cows,

It is proposed for the winter-spring period to keep the cattle on the lowest country, and separate from the sheep. Probably alternative (a) will be adopted, but (b) may be tried for another year until we are satisfied what suits us. 


\section{ENGINEEERING DEVELOPMENT}

\section{W A T E R}

"Ratahiwi" has now a system of piped water reticulation serving troughs in all paddocks as well as houses and sheds. Main supply is by gravity from a stream at the top of the farm, using some $38 \mathrm{~mm}$ pipe but largely $25 \mathrm{~mm}$ bore with the major length of the main constructed in a loop. Five 22750 litre tanks provide storage and, more importantly, break down static head and friction. Several smaller tanks act as headers on longer spur lines. There are about $20 \mathrm{~km}$ of pipe and 140 troughs.

If the intake fails, most paddocks are served by a pump harnessed to a spring; this takes over automatically as pressure falls.

\section{TREES}

As each section has been purchased, considerable expenditure has been necessary to remove old and troublesome trees, mainly radiata pine and other conifers.

\section{FENCING}

The fencing is now more or less adequate, with a system of races serving almost all paddocks. Some more subdivisioa will be done as opportunity offers. Electric fencing with a single wire was used very successfully for the weaners in winter-spring 1973 and will be used to a greater extent as more cattle are farmed. Electric fencing for sheep on the hills is still open to question and study.

\section{ROADING}

This is kept at a standard where we can gain access to anywhere on the farm quickly, and two $20 \mathrm{~m}$ bridges to carry 12 tonne loads were built in 1970 to serve the higher country with an all-weather 'access.

\section{DRAINAGE}

About 12 ha of wetter flats were tile drained in 1973, with reasonable results, but excavation costs were high. A further limited area will be drained and some "moling" is envisaged. Unfortunately, it is not possible to find extension workers to help design such schemes. 


\section{FER T ILIZER}

We have done a good deal of study on this subject, and are greatly indebted to P. R. Ball of Grasslands Division and his assistants who did much painstaking work on "Ratahiwi" with trials of all fertilizers over several years.

By 1969, we did not appear to be moving ahead on fertility and questioned our fertilizer policy to the extent of using no superphosphate over two summers, concurrently with Ball doing a number of plot trials, as well as paddock trials with nitrogen fertilizer.

Ball's work is not yet published, so details of results are not given here. However, results persuaded us to go to $314 \mathrm{~kg} / \mathrm{ha}$ of superphosphate per annum, 5 tha ground lime over two years, with the intention of using about $600 \mathrm{~kg} / \mathrm{ha}$ annual maintenance rate, and we moved in 1972 to $125 \mathrm{~kg} / \mathrm{ha}$ urea in late autumn on the lower country, particularly for cattle. We topdressed 22 ha in 1972, 120 in 1973, and 120 will be topdressed in 1974, this time with $45 \mathrm{t}$ of 16-9-O. Feed was short in spring 1972 so $65 \mathrm{~kg} /$ ha was applied to the hogget block with results which were particularly valuable in the ensuing dry season.

We are of the opinion that, once a strong ryegrass sward is available, the use of nitrogen can be most profitable, provided grazing management is good enough to both encourage responses and use what is grown.

\section{LABOUR}

Input has remained at two partners, and one shepherd, P. A. Selkirk, who has tolerated the writer's peculiarities for nine years. Obviously relations must have been reasonable for him to stay so long. We still crutch the hoggets in autumn, and the ewes and lambs before shearing. Shearing, winter ewe crutching, most fence construction, and topdressing are doae by contractors.

Hours worked are becoming less, time off is increasing, and the work seems to be kept up. Without doubt we would be struggling to do the necessary work without easy transport by motor cycles and landrovers.

\section{PROBLEMS REMAINING}

\section{INSECTS}

Considerable damage is being done to the pastures every year by porina caterpillar and grass grub. The combination of cost 
and variable results from the readily acceptable insecticides makes it very doubtful whether one should attack these pests, except for some effort at grazing management. We do not attempt any chemical control, and tolerate the resultant reduction of pasture production. Large increases in production will result if insecticides are more effective, or rather if more effective insecticides are allowed.

\section{RUShes AND DRAINAGE}

Much of our land is poorly drained and gleyed to some degree, resulting in invasion of Juncus spp., mainly J.gregiflorus. Some more drainage and better management practices, with occasional cultivation of valley land, will no doubt show gradual improvement.

\section{Avallability of Supplies and Services}

The general shortage of construction materials has not greatly affected us as we had no urgent large amounts of fencing and water reticulation to do by the time supplies became scarce.

Possibility of fertilizer shortage's, particularly the present world shortage of nitrogen, is serious. It seems to the layman that production of nitrogen in New Zealand, either direct from "Maui gas", or as a by-prcduct of heavy water manufacture, should become a matter of urgency, but it is doubtful if Government or potential large manufacturers have even thought seriously about the need for nitrcgen as fertilizer.

\section{Meat Processing}

For reasons outside the scope of this paper, the meat processing industry cannot kill all stock, particularly ewes, which farmers wish to slaughter during dry seasons. Until some improvement in killing speed can be made, we must expect the national ewe flock to reduce further in numbers. On "Ratahiwi", the shortage of feed from January to March each year is now the greatest factor keeping down flock size. If ewes were allowed to be killed at faster rates we would expect to winter a larger flock. If one is stccked higher in summer the answer is hand feeding, which is not very attractive to most operators, and we are suspicious of the economics of such a policy. 


\section{PASTURE TyPE}

We have moved from a low-producing pasture which effectively grew from October to March, to a fairly high-producing one of ryegrass (and clover) dominance which, with our treatment, will grow non-stop from March to December or with luck to some time in January.

As temperatures increase and mosture levels drop in the summer, the ryegrass often does not even stand - it rots away. Maintaining a rotation leads to major feed shortages in February. The current dry seasons are probably noticeable mainly because of higher stocking and our dependence on ryegrass, which grows so well in winter. Must we expect recurrent summer shortages and the costs of hand feeding; will some great advances be made which apply to this farm under the heading of, say, plant physiology; or are we just not yet up to standard in this facet of management?

\section{WHERE DO WE GO FROM HERE?}

If we knew, it would make life most uninteresting. It is an oldestablished fact that $\mathrm{H}$ omo sapiens is so constructed he can only be happy when he has something to strive towards. It is much better when one has a goal, but one must find the best of several routes, some of which are probably unknown.

We have a farm which is, by common standards, very well developed as a sheep unit, and we need only a reticulation system for electric fencing plus a few more troughs to run several groups of, say, 100 weaner cattle each. This, however, would result in a smaller area for sheep (unless we acquire more land). Do we then need more fences (smaller paddocks) for the sheep and are these to be electric or conventional?

Climate, soil and contour do not encourage cash cropping so we continue to look at "Ratahiwi" as a grazing enterprise. Probably considerable advances can be made by better breeding and management of the sheep flock, and grazing management better designed and executed, particularly by using cattle and nitrogen on units which have some basic drainage where needed. We will thus probably overcome the annoyance of rushes. Reticulation of the whole farm with $230 \mathrm{~V}$ electricity for fence leads, automatic gate opening and possibly electrostatic insect control may be economic in future, so we must study this possibility.

There are always possibilities of great advances coming from plant breeding and fertilizer research. Even without allowing for 
these, the greatest barrier is still ability of management. If we can make the pasture grow much faster, and therefore feed more animals better, can we alter our thinking and management to make use of the potential? Given that we have no pressing financial needs, are we prepared to? I think the answer is affirmative, and, when working on a reasonable scale, the possibility of increased producction and, more importantly, of greater personal or job satisfaction is still very great.

\section{REFERENCES}

Inglis, J. A. H., 1965: Proc. N.Z. Grassld Ass., 27: 46-55.

Rijkse, W. C., 1971: Soil map of the Woodville County. Department of Lands and Survey. (N.Z. Soil Bureau Map 96.) 